Research Article

\title{
Contamination of Groundwater Resources and its Impact on Milk Productivity and Efficiency of Dairy Farms: An Evidence from Punjab, Pakistan
}

\author{
Mahreen Alam*, Muhammad Ashfaq, Sarfraz Hassan and Asghar Ali
}

Institute of Agricultural and Resource Economics, University of Agriculture Faisalabad, Punjab, Pakistan. 3800.

Abstract | Poor groundwater quality is a fundamental problem for the dairy sector. Pakistan is ranked fourth
among the top ten milk-producing countries. However, it is also among those countries having the lowest
milk productivity. Milk yield is declining due to a number of factors, including water pollution. This study
was aimed to evaluate the effect of poor groundwater quality on the milk yield of dairy animals. Groundwa-
ter samples were analyzed for the Total Dissolved Solid, Electric Conductivity, and potential Hydrogen. The
groundwater quality was good at the tail, marginal at the middle, and poor at the head reaches of the distrib-
utary. Primary data were collected from 300 respondents along $11-\mathrm{L}$ distributary located in District Sahiwal,
Punjab-Pakistan during 2018-19. A stratified random sampling technique was used to collect data, and three
stratums like head, middle, and tail of $11-L$ distributary were selected based on groundwater quality. The re-
sults showed that the benefit-cost ratio for milk production was higher with good groundwater quality. The
Data Envelopment Analysis was used to calculate the technical efficiency. It found that farmers with good
groundwater quality were technically more efficient. Tobit model used to analyse the impact of water quality
parameters on the dairy animal's efficiency. It is concluded that water quality was minimizing the potential
gain from dairy animals. The study recommended that groundwater quality management be required to en-
hance the milk yield to improve the farming community's economic status.
Received | March 08, 2021; Accepted | October 22, 2021; Published | February 03,2022
"Correspondence | Mahreen Alam, Institute of Agricultural and Resource Economics, University of Agriculture Faisalabad, Punjab, Pakistan.
3800; Email: mahreenalam07@gmail.com
Citation | Alam, M., M. Ashfaq, S. Hassan and A. Ali. 2022. Contamination of groundwater resources and its impact on milk productivity and
efficiency of dairy farms: An evidence from Punjab, Pakistan. Sarbad Journal of Agriculture, 38(2): 430-438.
DOI | https://dx.doi.org/10.17582/journal.sja/2022/38.2.430.438
Keywords | Groundwater quality, Milk productivity, Benefit-cost ratio, Technical efficiency, Punjab-Pakistan

\section{Introduction}

G roundwater is a plentiful source of freshwaTer for all living organisms (Velis et al., 2017). Water has the ability to dissolve and absorb different compounds that are why water becomes easily polluted. Groundwater quality is the result of surrounding activities, and it varies with depth and place (Deeba et al., 2019). Pakistan is facing significant water stress due to an extremely inefficient irrigation system and low storage facilities. Groundwater quality is also effecting due to heavy and disproportionate use of fertilizers and pesticides in agricultural production (Shoemaker et al., 2017; Ran et al., 2016). In developing countries, rapid industrialization resulted in substantial losses in terms of ecosystem and agricultural production through water and air pollution. Water pollution is posing severe problems due to its impact on many economic activities (Reddy and Behera, 2006). Water resources are facing significant challenges due to high population growth and overuse of groundwater for agriculture. Groundwater extraction 
rate is greater in many places than its recharge, which compromises groundwater quality (Megdal, 2018).

Water is an essential nutrient for the dairy animal. It plays a crucial role in maintaining vital functions and production (Al-Mahdy, 2019). Water quality affects feed intake and the physiological health status of animals. Poor water quality is responsible for the poor performance and productivity of dairy animals (Giri et al., 2020). Limiting water intake by restricting access to or reducing consumption because of poor quality will decrease milk production (Linn, 2008). There are different water quality parameters like Electric conductivity $(\mathrm{Ec})$, potential hydrogen $(\mathrm{pH})$, Total Dissolved Solids (TDS), turbidity, mineral, temperature, Hardness, and microbial load. Livestock farmers are usually unaware of the importance of water quality for the performance and productivity of livestock. They can make a higher profit by reducing the productivity losses associated with poor water quality (Umar et al., 2014). In determining the quality of drinking water for livestock, TDS is considered a primary criterion. High TDS concentration reduced the animals' water intake, which decreased the milk yield (Tausif et al., 2018). The amount of TDS greater than $1000 \mathrm{ppm}$ is called saline water, and the use of this water decreases dairy animals' efficiency. Many experimental studies were conducted by providing a different concentration of TDS to the dairy animal. Results showed that the cattle that have direct access to clean drinking water have more weight than those who have no access to clean water. Cattle spent more time on grazing with access to good water, while cattle that had no proper access to clean water spent more time resting (Van-Eenige et al., 2013; Umar et al., 2014; Valtorta et al., 2008). Water from deep wells sa high salt content, so groundwater contains variable amounts of dissolved nutrients. Anthropogenic groundwater contamination is more likely in shallow aquifers as compare to deep aquifers (Chegbeleh et al., 2020; Lopez et al., 2016). Cattle productivity can be maintained if clean water is available. Cattle often refuse to consume salted water, which in turn also reduces the consumption of dry matter. Reduced consumption of nutrient intake has obvious impacts on beef productivity. The quality of milk also depends on quality of water intake by the animals (Giri et al., 2020).

The population is increasing rapidly. Milk is an essential food staff for the growing population in Pakistan. The burden on the dairy sector is increasing due to the high demand for dairy products. No doubt Pakistan is among the top 10 countries in milk production, but the milk yield is not satisfactory. The Punjab province is main a contributor to milk production. Poor drinking water quality reduced the milk yield because animals refuse to take poor quality water. The quality of groundwater is getting poor due to various human activities. Milk contains 87 percent of water, and the dairy animals required 4-5 liters of water to produce one liter of milk apart from their other water requirements (Ashraf et al., 2016). The livestock sector is a source of income for over 8 million rural families (GoP, 2019).

This study will make the farmer aware of the quality of water they are providing to their animal and what are their side impacts. When animal intake good quality of water, their production will be increased. It will improve the economic situation of the rural community. Regarding the study problem, it considered four main objectives. Firstly, assess the groundwater quality in the research area. Secondly, the economic benefits of various drinking water qualities were measured. Thirdly, the technical efficiency of feed intake was calculated. Finally, to highlight the impact of different drinking water quality parameters on the efficiency of feed intake by dairy animals.

\section{Materials and Methods}

The district Sahiwal has prime importance in agriculture. The total area of the district is $3201 \mathrm{~km}^{2}$, with around 7.3 million inhabitants. The weather is hot, with an average rainfall of $177 \mathrm{~mm}$. It is situated 150 $\mathrm{m}$ above sea level (Khalid et al., 2017). Groundwater quality varies in the Sahiwal district from good to saline (Ishaq et al., 2016). Dairy Farming is the principal survival source in the study area. Due to abased groundwater quality, farm output is declining. Farmers have livestock to compensate for the crop losses. But the dairy sector is also badly affected by poor groundwater quality (Shine et al., 2020). The sewerage system is absent in many villages of the study area and groundwater quality is highly variable. The District Sahiwal is further divided into two tehsils like Sahiwal and Chichawatni. The 11-L distributary was selected, located in Chichawatni tehsil because the quality situation along the distributary was highly variable and the management practices were almost the same. Along the 11-L distributary, a total of 27 villages were located, and 15 were selected randomly 


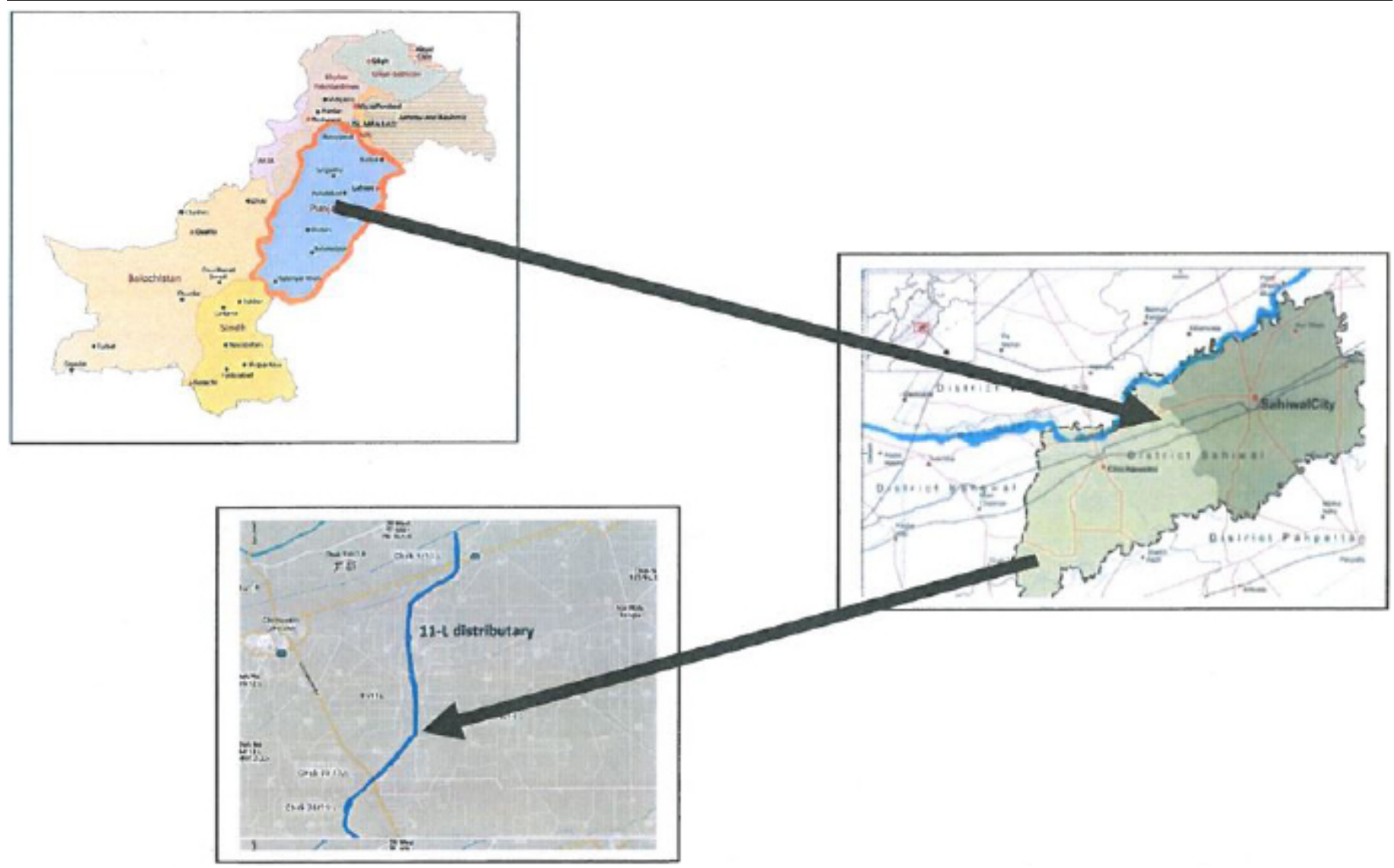

Figure 1: Study area.

from the head, middle, and tail of the distributary. A total of 100 respondents were randomly selected from 5 villages at each location (Figure 1).

\section{Groundwater sampling}

Water quality is the main determent of the current study. It is a prerequisite to test water quality before data collection. Groundwater samples were collected along the 11-L distributary, which is in District Sahiwal. A total of 110 samples were collected from the head, middle and tail reach of the distributor. Two samples were wasted during transportation. Samples were collected from different sources like tube well, hand pumps, and electric motors. Two samples were collected from each source. Samples were collected in clean plastic bottles. To examine groundwater quality variation, 108 samples were submitted to Ayoub Agriculture Research Center (AARC) for analysis. The water samples reports contain information about Electric conductivity (EC), Calcium, and Magnesium $(\mathrm{Ca}+\mathrm{Mg})$. Sodium $(\mathrm{Na})$, Carbonate $\left(\mathrm{CO}_{3}\right)$, Bicarbonates $\left(\mathrm{HCO}_{3}\right)$, Chloride (CI), Sodium Adsorption Ratio (SAR), Residual Sodium Carbonate (RSC), pH, and total suspended salt (TSS). Lab results showed that the groundwater quality was poor at the head reach of the distributary marginal at the middle and good at the tail reach of the distributary.

\section{Data collection}

Primary data were collected from 300 respondents after pre-testing of the questionnaire to make sure the validity of the data. Data were collected using a stratified random sampling technique. As groundwater quality was different at the head, middle, and tail reaches so these three locations were selected as strata for the data collection. Groundwater samples were again tested for Ec, TDS, and $\mathrm{pH}$ using pieosometer before data collection. Due to financial constraints, all the samples were not tested for all the parameters tested for site selection.A total of 100 farmers, were randomly interviewed from each stratum. Data were collected about all the aspects related to variable costs of a single animal and revenue generated by milk production. Data were collected during the year 20182019 (Table 1).

\section{Benefit-cost ratio}

Benefit-cost ratio (BCR) is an instrument to assess the economic benefits of activity with respect to the economic costs of that activity which is shown in equation 1. Economic returns influenced the farmer's choices regarding resource allocation. It is the ratio of the present value of benefits and the present value of costs (Dipu et al., 2019; Diro et al., 2019; Shah et al., 2009). 


$$
B C R=\frac{\text { Total revenue }}{\text { Total cost }}
$$

Table 1: Sampling framework.

$\begin{array}{lllll}\begin{array}{l}\text { Study } \\ \text { Area }\end{array} & \begin{array}{l}\text { Name Dis- } \\ \text { tributary }\end{array} & \begin{array}{l}\text { Locations of } \\ \text { distributary }\end{array} & \begin{array}{l}\text { Number of } \\ \text { Villages }\end{array} & \begin{array}{l}\text { No of Re- } \\ \text { spondents }\end{array} \\ \text { Sahiwal } & \text { 11-L distrib- } & \text { Head } & 5 & 100 \\ \text { District } & \text { utary } & \text { Middle } & 5 & 100 \\ & & \text { Tail } & 5 & 100 \\ \text { Total } & - & - & 15 & 300\end{array}$

\section{Data Envelopment Analysis (DEA)}

DEA is a non-parametric technique that used mathematical tools to obtain an empirical estimation of relationships (Toma et al., 2015). DEA evaluates the performance of peer entities known as decision-making units (DMUs). DMUs are treated as fully efficient when inputs and outputs cannot be improved without worsening the other inputs and outputs (Cooper et al., 2011). Data Envelopment Analysis (DEA) is widely used to measure the technical and economic efficiency in all the possible fields of life. DEA was firstly introduced by Cooper and Rhodes in 1978. It is used to measure the performance that measures the relative efficiency of decision-making units (Toma et al.,2015). This technique is used in agriculture to analyze the performance of this sector using various inputs and outputs. The input-oriented variable return to scale DEA analysis was conducted by using Deap software. Input-oriented efficiency measures indicate proportionate reductions in quantities of inputs without reducing the output quantity produced (Madau et al., 2017). The input-oriented measure of TE of the jth DMU is calculated by solving the following linear programming model.

Min $\theta$

Subject;

$$
\begin{gathered}
-y i+Y \lambda \geq 0 \ldots \ldots(2) \\
\theta x i-X \lambda \geq 0 \ldots .(3) \\
\lambda \geq 0,0 \leq \theta \leq 1 \ldots .(4)
\end{gathered}
$$

The input-oriented DEA looks for a minimal possible contraction of all inputs that give the same output level. Mathematical modelling has been shown in equation 2, 3 and 4 respectively. Here $Y \lambda$ is the output of best DMU and $y_{i}$ is the output of $i^{\text {th }}$ DMU, $\mathrm{X} \lambda$ is the combination of best DMU, and $\theta$ xi is the combination of inputs of $i^{\text {th }}$ decision-making unit. Notice that $\theta$ is a real variable that measures the TE.
The DMU is inefficient if there $\theta<1$ If $\theta=1 \mathrm{DMU}$ is efficient (Al-Sharafat, 2013; Gelan and Muriithi, 2012).

\section{Tobit regression analysis}

The Tobit model deals with a continuous dependent variable that is constrained in nature. The Tobit regressions are suitable for modeling, in which the dependent variable is bounded between two values. The value of the dependent variable cannot move away from those boundaries. The dependent variable is bounded between zero and one; it cannot take values less than zero and greater than one (Odah et al., 2018). In this study, Tobit regression analysis is used to measure the relationship between the water quality parameters and the efficiency of the dairy animal. Tobit Regression Analysis used instead of Logit and Probit Regression because of censored dependent variable of efficiency of dairy animal. It produces consistent parameter estimates (Minten et al., 2020). Mathematical form of model is shown in equation 5.

\section{Tobit model for cow}

Mathematical Tobit model for cow has been shown in equation 5 .

$$
\begin{gathered}
\ln Y i=\gamma_{0}+\gamma_{1} \ln X_{1 i}+\gamma_{2} \ln X_{2 i}+\gamma_{3} \ln X_{3 i}+\gamma_{4} \ln X_{4 i}+ \\
\mu_{i} \ldots \ldots \ldots .(5)
\end{gathered}
$$

Where;

$Y_{i}$ : Efficiency of cow's milk production; $X_{1}$ : Ec value of $\mathrm{GW} ; \mathrm{X}_{2}: \mathrm{pH}$ value of $\mathrm{GW} ; \mathrm{X}_{3}$ : TDS value of $\mathrm{GW}$; $\mathrm{X}_{4}$ : Breed; $\mu_{\mathrm{i}}$ : Error term.

\section{Tobit model for buffalo}

Tobit model for buffalo is shown in equation 6 .

$$
\ln Y_{i}=\omega_{0}+\omega_{1} \ln X_{1 i}+\omega_{2} \ln X_{2 i}+\omega_{3} \ln X_{3 i}+\mu_{i} \ldots
$$

Where;

$Y_{i}$ : Efficiency of Buffalo's milk production; $X_{1}$ : Ec value of $\mathrm{GW} ; \mathrm{X}_{2}: \mathrm{pH}$ value of $\mathrm{GW} ; \mathrm{X}_{3}$ : TDS value of $\mathrm{GW} ; \mu_{\mathrm{i}}$ : Error term.

\section{Results and Discussion}

The results of water analysis showed that the groundwater quality at the head was unfit at the middle was marginally fit and good at tail reaches of the distributary, as shown in Table 2. It was a general perception that the groundwater quality remains good at the head 
reach of the distributary and poor at the tail reaches of the distributary. In the current study, the quality situation was reversed. The reason for this result was that the $11-\mathrm{L}$ distributary is $95 \%$ lined in head and middle reaches, while $45 \%$ lined in the tail areas. Due to the unlined distributary, the water seepage is higher at the tail that improves the groundwater quality at the tail. The flow of water was also higher toward the tail because of the political powers that influence the canal water distribution.

Table 2: Groundwater quality situation in the study area.

$\begin{array}{llll}\text { Items } & \text { Mini } & \text { Max } & \text { Average } \\ \text { Head } & & & \\ \text { Ec }(\mu \mathrm{S} / \mathrm{cm}) & 850 & 2520 & 1677.69 \\ \text { TDS }(\mathrm{ppm}) & 544 & 1621.80 & 1073.72 \\ \mathrm{pH} & 7.16 & 9.01 & 7.82 \\ \text { Middle } & & & \\ \text { Ec }(\mu \mathrm{S} / \mathrm{cm}) & 725 & 1576 & 1284.65 \\ \text { TDS }(\mathrm{ppm}) & 464 & 1008.64 & 822.17 \\ \mathrm{pH} & 7.06 & 129 & 9.17 \\ \text { Tail } & & & \\ \text { Ec }(\mu \mathrm{S} / \mathrm{cm}) & 475 & 995 & 738.25 \\ \text { TDS }(\mathrm{ppm}) & 304 & 636.80 & 472.45 \\ \mathrm{pH} & 7 & 10.31 & 8.42\end{array}$

Source: Authors on analysis.

Water plays an important role in the better production of milk. A high TDS level significantly reduces the milk yield (Tausif et al., 2018). Milk is provided primarily by cows and buffalo for human consumption (Cardot et al., 2008). An experimental study was conducted by Arjomandfar et al. (2010) that concluded that milk yield was higher by 2 litres per animal per day with good drinking water quality. The drinking water quality at the tail was good; that is why the average milk yield per animal per day was higher at the tail location. Milk production per animal per day is given in Figure 2.

\section{Benefit-cost ratio of milk production}

Income from the dairy sector plays an important role in bringing the rural community out of poverty situations (Jaiswal et al.,2018). Drinking water quality and quantity significantly affect milk production. Animals take less water if it is saline (Umar et al., 2014). Milk production declines with less water intake (Ashraf et al., 2016). Low water intake increased blood urea, decreased respiratory rate and also decreased body weight (Cardot et al., 2008). Farmers provided water two or three times a day in the study area, but farmers indicated that, due to poor drinking water quality, animals did not take much water. Feed full of nutrients is the key element to stimulate the milk yield and make a better composition of it (Krizsan et al., 2014). The production of milk depends on nutrition by 70 percent. Poor nutrition not only reduces the milk yield but also reduced the fertility of dairy animals. If animals are fed well, more milk could be extracted from them with good management (Garamu, 2019). Feed cost includes the cost of fodder, wheat straw and concentrates, etc. Other cost includes animal health cost and infrastructural cost. The average milk production was higher at the tail as compared to the head and middle. The benefit-cost ratio showed that the farmers at tail were getting more benefits from dairy animals, as shown in Table 3.

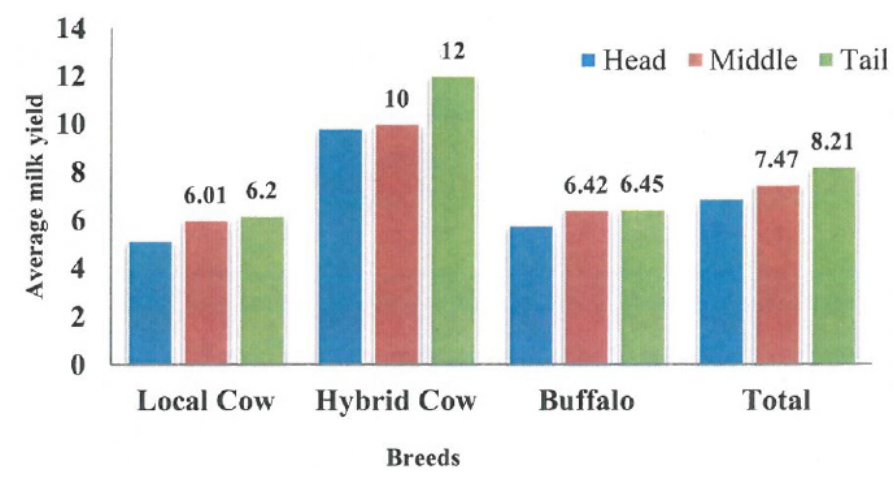

Figure 2: Milk production with respect to breed (Liters/per animal/ day).

Table 3: benefit cost analysis of dairy animals.

$\begin{array}{lcll}\text { Factor } & \text { Head } & \text { Middle } & \text { Tail } \\ \text { Benefit cost analysis for cow } & & \\ \text { Feed Cost } & 174.16 & 197.4 & 171.07 \\ \text { Other cost } & 57.84 & 53.51 & 33.87 \\ \text { Buffalo milk yield } & 5.13 & 6.01 & 6.22 \\ \text { Price } & 55.37 & 54.96 & 55.64 \\ \text { Revenue } & 282.04 & 330.50 & 346.08 \\ \text { BCR } & 1.22 & 1.32 & 1.68 \\ \text { Benefit cost analysis for buffalo } & & \\ \text { Feed Cost } & 238.01 & 232.39 & 220.63 \\ \text { Other cost } & 57.84 & 53.51 & 33.87 \\ \text { Buffalo milk yield } & 5.67 & 6.35 & 6.65 \\ \text { Price } & 65.37 & 65.18 & 65.86 \\ \text { Revenue } & 370.64 & 413.89 & 437.96 \\ \text { BCR } & 1.24 & 1.44 & 1.72\end{array}$

Source: Authors own calculation.

Technical efficiency of cow and buffalo June 2022 | Volume 38 | Issue 2 | Page 434 
The input-oriented DEA model was used to calculate the technical and economic efficiency of dairy animals. The entire possible feed intake used to calculate technical efficiencies like fodder, Concentrate, Wheat straw, and water. Table 4 shows that at the head, the mean technical efficiency was 59 percent. It means that milk yield can be increased by 41 percent using the same quantity of inputs. The mean technical efficiency at middle and tail was 63 and 71, respectively.

Table 4: Technical efficiency of dairy animals.

\begin{tabular}{lllllll} 
Categories & \multicolumn{1}{l}{ Cow } & \multicolumn{5}{c}{ Buffalo } \\
& Head & Middle & Tail & Head & Middle & Tail \\
$0.40-0.50$ & 38 & 28 & 10 & 2 & 2 & 4 \\
$0.50-0.60$ & 11 & 8 & 17 & 11 & 2 & 3 \\
$0.61-0.70$ & 13 & 18 & 18 & 8 & 6 & 13 \\
$0.71-0.80$ & 8 & 16 & 12 & 16 & 16 & 12 \\
$0.81-0.90$ & 4 & 4 & 7 & 15 & 11 & 14 \\
$0.91-1.00$ & 6 & 14 & 27 & 15 & 40 & 39 \\
Mean & 0.59 & 0.63 & 0.71 & 0.78 & 0.86 & 0.93
\end{tabular}

Al -Sharafat (2013) also determined the average technical efficiency of dairy animals that was only 39.5 percent. Yilmaz et al. (2020) look at 92 dairy farmer's average technical efficiency. The estimated technical efficiency was 55 percent, which means that a typical dairy farmer would increase milk yield by 45 percent without using any additional inputs. In the case of buffalo, the mean technical efficiency was 78,86 , and 93 percent at the head, middle, and tail, respectively. It means that a 22,14 , and 7 percent increase is possible using the same quantity of feed intake.

According to Guadalupe et al. (2015), the milk production efficiency was 17 percent higher with desalinated water. Cows with desalinated water had health and production efficiency benefits. The sources of variation in technical efficiency among various DMUs for better policy recommendations. Thus, several qualities related factors were regressed upon the efficiency scores to identify the determinants of efficiencies. Table 5 shows that the quality variables have a negative impact on the efficiency of milk production of cows.

Buffalo is considered the best dairy animal in Pakistan, and its milk constitutes about $62 \%$ of total milk production. Animals are quite sensitive to water quality and prefer to take clean water without any adulteration. Total dissolved solids is the sum of inorganic matter dissolved in water, which is considered to be the main criterion in the assessment of the quality of drinking water for livestock (Tusife et al., 2019). The findings of Tobit models revealed that $\mathrm{Ec}$ and $\mathrm{pH}$ have a negative but non-significant effect on dairy animal efficiency, as shown in Table 5. The efficiency of the cow and buffalo is reduced by 0.004 and 0.007 points, respectively, when the Ec value is increased by one unit. The efficiency of the cow and buffalo is reduced by 0.003 and 0.040 , respectively, when the $\mathrm{pH}$ value is increased by one unit. TDS showed negative and significant impacts on the efficiency of cow and buffalo. One unit increase in TDS reduces the efficiency of cow and buffalo by 0.009 and 0.001 points. In the case of the cow, local and hybrid cow was reared, and hybrid cow has a significant positive impact on efficiency. All farmers were raring local buffalo, so this variable is missing in the case of buffalo. Local and hybrid cows were reared in the study area; hybrid cows had a substantial positive effect on efficiency. This variable is absent in the case of buffalo since all farmers were raring only local buffalo.

Table 5: Tobit model results for factors affecting cow's milk production.

$\begin{array}{lll}\text { Variables } & \text { Cow } & \text { Buffalo } \\ \text { Constant } & 0.62^{*}(0.000) & 0.59^{*}(0.004) \\ \text { Ec-Value } & -0.004(0.322) & 0.007(0.185) \\ \text { pH-Value } & -0.003(0.788) & 0.040(0.241) \\ \text { TDS } & -0.001^{*}(0.023) & -0.009^{*}(0.016) \\ \text { Breed } & 0.15^{*}(0.011) & -\end{array}$

Note: "significant at 5\%

\section{Conclusions and Recommendations}

Water is an essential nutrient for dairy animals. The drinking water quality affects animal performance. Poor water quality compels the animal to reduce the water intake. The groundwater quality gets improved when moving from head to tail reaches of the distributary, so the average milk yield also improves in the same way. The average milk yield at head, middle, and tail was 6.90, 7.47, and 8.21 liters, respectively. Farmers were offering groundwater without testing its quality. The drinking water quality check is required on a regular basis. The technical efficiency was also reduced with poor drinking water quality. The average technical efficiency for dairy animals was better at the tail reach of the distributary. This study was conducted during the winter months, and behavioural effects 
may be different during the heat of summer when cows need more water per day. The study recommended that groundwater quality management be required to enhance the milk yield to improve the farming community's economic status. Local cow, hybrid cow, and buffalos were rearing in the study area. Benefits cost ratio showed that the heavy economic benefits are present in the rearing of the hybrid cow as compare to local cow and buffalo. The technical efficiency for buffalo was comparatively high for buffalo. It will be economically beneficial to have more local buffalo as compare to the local cow. Domestic and industrial wastes are contributing to polluting the groundwater resources. There is a need to reduce the TDS level in groundwater resources by developing a proper waste management system. Regulations should be revised for industries to manage their waste.

\section{Acknowledgments}

The authors gratefully acknowledge the support of the project "Improving Salinity and Agricultural Water Management in the Indus Basin of Pakistan" (Project number LWR/2017/028).

\section{Novelty Statement}

In Pakistan lot work has done on groundwater quality, but very little literature available related to its impact of dairy produc-tivity. The study is a combination of experimental and survey study.

\section{Author's Contribution}

Mahreen Alam: Main idea, data collection, data analysis and write up.

Muhammad Ashfaq: Refinement in methodology and write up.

Sarfraz Hassan: Performed economic modelling.

Asghar Ali: Wrote discussion and conclusion.

\section{Conflict of interest}

The authors have declared no conflict of interest.

\section{Reference}

Al-Sharafat, A. 2013. Technical efficiency of dairy farms: A stochastic frontier application on dairy farms in Jordan. J. Agric. Sci., 5(3): 45. https:// doi.org/10.5539/jas.v5n3p45
Arjomandfar, M., M.J. Zamiri, E. Rowghani, M. Khorvash and G. Ghorbani. 2010. Effects of water desalination on milk production and several blood constituents of Holstein cows in a hot arid climate. Iranian J. Vet. Res., 11(3): 233-238.

Ashraf, M.S., Z. Manzoor, N. Khan, T. Abbas, Z. Mustafa and M.N.M. Ibrahim. 2016. Effect of water and balanced diet on milk production of dairy animals in Pakistan. Tropical Animal Science and Production. $1^{\text {st }}$ International Conference on Tropical Animal Science and Production July 26-29, 2016 Ambassador Hotel, Thailand. 1-5.

Cardot, V., Le Roux, Y. and Jurjanz, S. 2008. Drinking behavior of lactating dairy cows and prediction of their water intake. J. Dairy Sci., 91(6): 2257-2264. https://doi.org/10.3168/jds.20070204

Chegbeleh, L.P., B.A. Akurugu and S.M. Yidana. 2020. Assessment of Groundwater Quality in the Talensi District, Northern Ghana. Sci. World J. 2020: 1-24. https://doi. org/10.1155/2020/8450860

Cooper, W.W., L.M. Seiford and J. Zhu. 2011. Handbook on data envelopment analysis. Second edition. https://doi.org/10.1007/978-14419-6151-8

Deeba, F., N. Abbas, M.T. Butt and M. Irfan. 2019. Ground water quality of selected areas of Punjab and Sind Provinces, Pakistan: Chemical and microbiological aspects. Chem. Int. 5(4): 241246. https://doi.org/10.2139/ssrn.3407494

Dipu, S.M.M.A., M.R. Begum and S. Sultana. 2019. Socio-economic, farm and technological characteristics of the peri-urban small and marginal dairy farmers of Chittagong metro area, Bangladesh. SAARC J. Agric. 17(1): 77-91. https://doi.org/10.3329/sja.v17i1.42763

Diro, S., W. Getahun, A. Alemu, M. Yami, T. Mamo and T. Mebratu. 2019. Cost and Benefit Analysis of Dairy Farms in the Central Highlands of Ethiopia. Ethiopian J. Agric. Sci. 29(3): 29-47.

El-Mahdy, C.I. 2019. Importance of Fresh Water for Livestock. 29-34. https://www.researchgate. net/publication/335549106_Importance_of_ Fresh_Water_for_Livestock

El-Mahdy, C., A. Boaru, S. Popescu and C. Borda. 2016. Water quality, essential condition sustaining the health, production and reproduction in cattle. A review. Bulletin of the University 
of Agricultural Sciences \& Veterinary Medicine Cluj-Napoca. Anim. Sci. Biotech., 73(2):1-14. https://doi.org/10.15835/buasvmcn-asb:12156

Gelan, A. and B.W. Muriithi, B.W. 2012. Measuring and explaining technical efficiency of dairy farms: a case study of smallholder farms in East Africa. Agrekon, 51(2): 53-74. https://doi.org/ 10.1080/03031853.2012.695140

Garamu. K. 2019. Significance of feed supplementation on milk yield and milk composition of dairy cow. Dairy Vet. Sci. J., 13: 555860.

Government of Pakistan (GOP). 2019. Economic survey of Pakistan. 2019. Government of $\mathrm{Pa}-$ kistan, Finance division, Economic Advisor's wing, Islamabad. Pakistan.

Guadalupe, G.M. J., Herrera-Monsalvo, C.D., Lara-Bueno, A., López-Ordaz, R., JaimesJaimes, J. and Ramírez-Valverde, R. 2015. Effects of drinking water desalination on several traits of dairy cows in a Mexican semiarid environment. Life Sci. J., 12(2s).

Giri, A., V.K. Bharti, S. Kalia, A. Arora, S.S. Balaje, S.S. and O.P. Chaurasia, O.P. 2020. A review on water quality and dairy cattle health: a special emphasis on high-altitude region. Appl. Water Sci., 10(3): 1-16. https://doi.org/10.1007/ s13201-020-1160-0

Ishaq, M., S.M. Mehdi, M. Jamil, A.A. Rahi and M.Q. Masood. 2016. Irrigation quality status of tube-well waters and management for sustained crop production in Canal Command Areas of district Sahiwal. J. Agric. Res., (03681157). 54(3):383-393.

Jaiswal, P., Chandravanshi, H. and Netam, A. 2018. Contribution of dairy farming in employment and household nutrition in India. Int. J. Avian Wild. Biol., 3(1):78-79. https://doi. org/10.15406/ijawb.2018.03.00059

Khalid, U.B., P.S.U.H. Shahbaz and S. Javeed. 2017. Economic Analysis of Integrated Farming Systems on Farm Income. A case Study of Sahiwal District, Punjab, Pakistan. Int. J. Manage. Econ. Invention, 3(1): 1434-1444. https://doi. org/10.18535/ijmei/v3i11.07

Krizsan, S.J., Sairanen, A., Hojer, A. and P. Huhtanen, P. 2014. Evaluation of different feed intake models for dairy cows. J. Dairy Sci., 97(4): 2387-2397. https://doi.org/10.3168/jds.20137561

Linn, J. 2008. Impact of minerals in water on dairy cows. Dairy Star, (17): 13-20.
Lopez, A., J.I. Arroquy and R.A. Distel. 2016. Early exposure to and subsequent beef cattle performance with saline water. Livestock Sci., 185: 68-73. https://doi.org/10.1016/j.livsci.2016.01.013

Madau, F.A., R. Furesi and P. Pulina. 2017. Technical efficiency and total factor productivity changes in European dairy farm sectors. Agric. Food Econ., 5(1): 1-14. https://doi. org/10.1186/s40100-017-0085-x

Megdal, S.B. 2018. Invisible water: the importance of good groundwater governance and management. Clean Water, 1(1): 1-5. https://doi. org/10.1038/s41545-018-0015-9

Minten, B., Y. Habte, S. Tamru and A. Tesfaye. 2020. The transforming dairy sector in Ethiopia. PLoS ONE, 15(8): e0237456.

Odah, M.H., B.K. Mohammed and A.S.M. Bager. 2018. Tobit regression model to determine the dividend yield in Iraq. LUMEN Proceed., 3:347-354

Ran, Y., M. Lannerstad, M. Herrero, C.E. Van Middelaar and I.J.M. De Boer. 2016. Assessing water resource use in livestock production: A review of methods. Livestock Sci., 187: 68-79. https://doi.org/10.1016/j.livsci.2016.02.012

Reddy, V.R. and B. Behera. 2006. Impact of water pollution on rural communities: An economic analysis. Ecol. Econ., 58: 520-537. https://doi. org/10.1016/j.ecolecon.2005.07.025

Shah, A., A. Saboor and S. Ahmad. 2009. An estimation of cost of milk production in Pakistan: A microeconomic approach. Sarhad J. Agric., 25(1): 141-147.

Shine, P., M.D. Murphy and J. Upton.2020. A global review of monitoring, modeling, and analyses of water demand in dairy farming. Sustainability, 12(17): 7201. https://doi.org/10.3390/ su12177201

Shoemaker, C.M., G.N. Ervin and E.W. Diorio. 2017. Interplay of water quality and vegetation in restored wetland plant assemblages from an agricultural landscape. Ecol. Engineer., 108: 255-262. https://doi.org/10.1016/j.ecoleng.2017.08.034

Tausif, M.A., F. Shahzad, J.A. Bhatti, S. Qamar, A. Khalique, H.U. Rahman and A. Hussain. 2018. Effect of water quality on production performance of lactating Nili-Ravi buffaloes. Turkish J. Vet. Anim. Sci., 42(6): 543-548. https://doi. org/10.3906/vet-1703-88 
Toma, E., C. Dobre, I. Dona and E. Cofas. 2015. DEA applicability in assessment of agriculture efficiency on areas with similar geographically patterns. Agric. Agric., Sci. Procedia, 6(1): 704-711. https://doi.org/10.1016/j.aaspro.2015.08.127

Umar, S., M.T. Munir, T. Azeem, S. Ali, W. Umar, A. Rehman and M.A. Shah. 2014. Effects of water quality on productivity and performance of livestock: A mini review. Veterinaria, 2:1115.

Valtorta, S.E., Gallardo, M.R., Sbodio, O.A., Revelli, G.R., Arakaki, C., Leva, P.E. and Tercero, E.J. 2008. Water salinity effects on performance and rumen parameters of lactating grazing Holstein cows. Int. J. Biometeorol., 52(3): 239-247. https://doi.org/10.1007/s00484-007-0118-3

Van Eenige, M.J., G.H. Counotte and J.P. Noordhuizen. 2013. Drinking water for dairy cattle: always a benefit or a microbiological risk?. Tijdschrift voor diergeneeskunde, 138(2): 86-97.

Velis, M., K.I. Conti and F. Biermann. 2017. Groundwater and human development: synergies and trade-offs within the context of the sustainable development goals. Sustain. Sci., 12(3): 1007-1017. https://doi.org/10.1007/s11625017-0490-9

Yilmaz, H., F. Gelaw and S. Speelman. 2020. Analysis of technical efficiency in milk production: a cross-sectional study on Turkish dairy farming. Revista Brasileira de Zootecnia, 49:1-10. https://doi.org/10.37496/rbz4920180308 